\title{
Kleos, Nostos and Ponos in Homeric Tradition
}

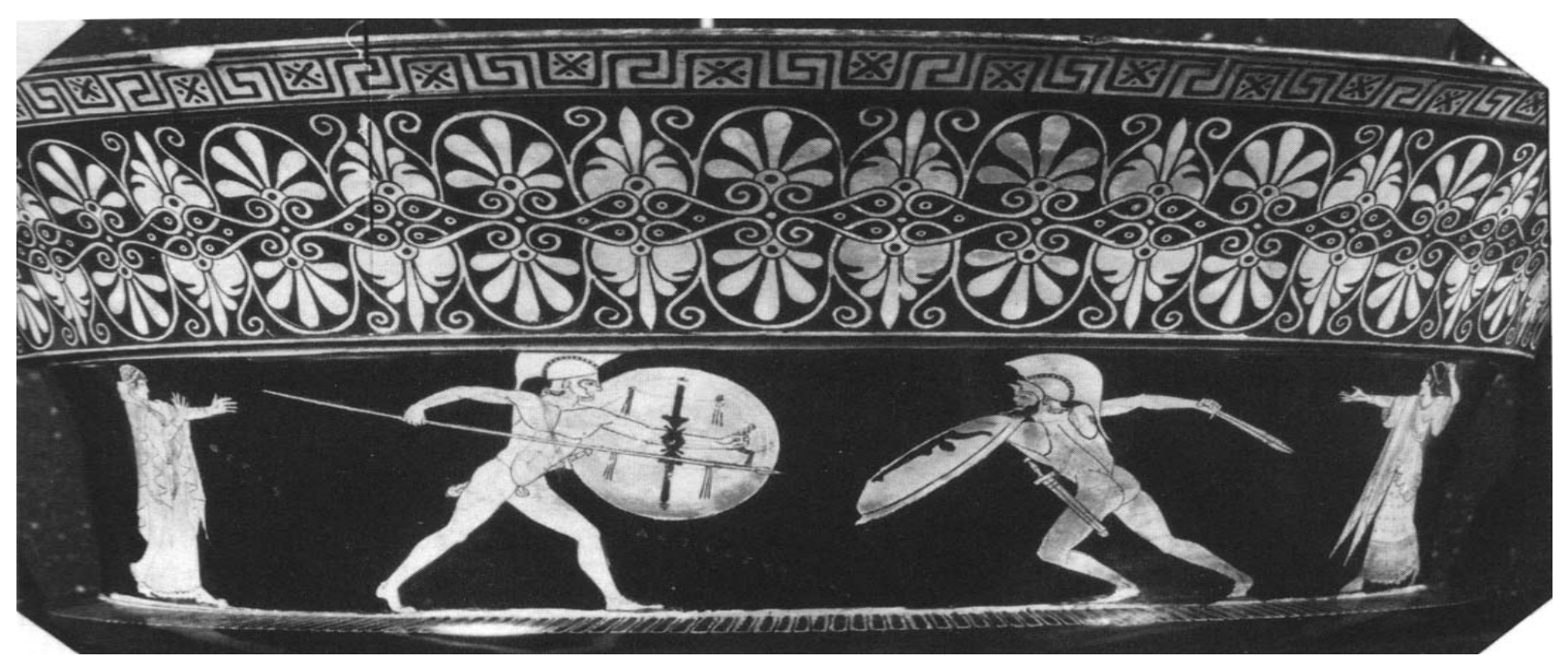

DOI: 10.13150/CQ.2.2.18533.19687

\begin{abstract}
This paper analyses meaning and connectedness of Kleos (eternal glory, fame), Nostos (homecoming, heroic return) and Ponos (toil, ordeal, pain) in various myths from including the Iliad, the Odyssey and the Epic Cycle ${ }^{1}$. Despite being essential to the analysing cultural significance of Homeric tradition, folklore feels disconnected from initial manifestations of heroic stories. We can say that such unfortunate outcome is caused by the popularity of non-poetic narratives that have been created by numerous writers to bring the coherent plot into the foreground. This approach might be comprehensible presentation of the story, though such versions lack the essence of imprinting heroic deeds into epic poems by earning Kleos and sustaining heroes' Kleos by repeated performance. Thus, this essay explores significance of Kleos, nostos and Ponos within Homeric tradition and suggests that we should abandon a canonical way of reading these virtues because such approach does not correspond with original myths that had been passed down from generation to generation. For this purpose, abovementioned heroic virtues will be demonstrated on examples of Odysseus, Diomedes, Telemonian Ajax, Neoptolemus and with emphasis on Achilles - the epitome of Kleos. Moreover, popular adherence to "multi-volume" way of reading the Trojan War will be re-evaluated by juxtaposing Homer's works and the Epic Cycle to locate distinct traditions regarding Kleos, Nostos and Ponos.
\end{abstract}

\section{The Role of Destiny in Hero's Journey}

One of the first points that should be discussed is undoubtedly a connection between Achilles's struggle toward earning Kleos in Homer's Iliad and involvement of Greek goddess Eris². Since we know that Eris stands for "discord" and she was the only one goddess, who was not invited to wedding of
Achilles' parents, we can assume that her gatecrashing and subsequent showmanship with the apple labelled as "for the most beautiful" implies that destiny of Achilles will be tied to the result of "apple-beauty contest" - the Trojan War'. Moreover, Eris's son is god of hard labour called Ponos, but a word "Ponos" is also commonly used for ordeal regarding heroic themes in the Epic Cyclet. Hence, we can

\footnotetext{
${ }^{1}$ Aristotle Poetics $1459 a-b$

${ }^{2}$ Homer, The lliad book IV. 411

${ }^{3}$ West, Martin. "Greek Epic Fragments from the Seventh to the Fifth Centuries BC Cambridge." (2003), p.67 - 69

${ }^{4}$ Archaic and Classical Choral Song: Performance, Politics and Dissemination edited by Lucia Athanassaki, Ewen Lyall Bowie, 178, see also - Quintus Smyrnaeus

By Manuel Baumbach, Nicola Dümmler, p. 272-274
} 
use Ponos as the ordeal to shed more light on Achilles' destiny of being unable to earn both Kleos and Nostos.

Achilles' momentum of Kleos is not overcoming grief and loss of Patroclus or killing Hector, but it is his ability to end discord between him and Agamemnon and return to fight, which in turn leads to the possibly of avenging Patroclus' death and therefore completing the circle and earning $\mathrm{Kleos}^{5}$. There is an evident link between goddess Eris (Discord) and Achilles' ultimate obstacle separating him from earning Kleos and thus discord functions as Eris' curse, which prevents Achilles' to fulfil his destiny. Since Achilles is usually branded by Homer as "best of the Achaeans", earning Kleos is not and optional outcome for him, but it is merely proof that he is worthy of his name and destiny ${ }^{6}$. This suggests that Achilles must go through Ponos in the form of personal ordeal by solving disputes with Agamemnon to avenge his friend Patroclus and kill Hector. In this point, we should apply Joseph Campbell's revised and expanded version of the classical Jungian concept of Hero's Journey, which might serve to clarify Achilles' case.

First, it is necessary to realise that Homer's Iliad is focused precisely on Achilles as the main protagonist and therefore he is undoubtedly the hero of Homer's story, even though other Achaeans and Trojans plays significant roles as well. The very beginning of the Iliad begins with Achilles' rage caused by Agamemnon's abduction of Briseis and subsequent refusal to fight for Agamemnon, which unfortunately means that Achilles might not earn Kleos at all. Achilles' ultimate decision to fight for Kleos is essential for the continuation of hero's journey and withstanding the supreme ordeal to find

\footnotetext{
${ }^{5}$ Homer, The Iliad, book IX. 411-415

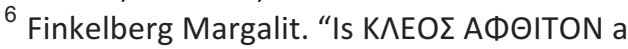
Homeric Formula?" Classical

Quarterly, 35:1-5

${ }^{7}$ Campbell, Joseph. The hero with a thousand faces. Vol. 17. New World Library, 2008, p. 89, 186, see also - Jung, Carl Gustav. The archetypes and the collective unconscious. Routledge, 2014, p. 128

${ }^{8}$ Mackie, Hilary. "Song and storytelling: an Odyssean Perspective." Transactions of the American Philological Association (1974-) 127 (1997), p. 77-85
}

the elixir in Jungian words ${ }^{7}$. The key to understating of Achilles' role lies in the definition of Achilles' as the "Hero" (main protagonist of the Iliad) and Achilles' role as Homeric archetype of the hero in the Epic Cycle. Achilles' role in the Aethiopis, the Little Iliad, the Sack of Ilium or the Odyssey is either recurring or marginal since other plots are focused on different characters and motifs ${ }^{8}$. Moreover, the Trojan war is mainly covered in two different groups of myths, stemming from Homer's oral tradition including the Iliad and the Odyssey or either distinct oral tradition of the Epic Cycle passed down by various poets such as Agias of Troezen, Lesches of Mitylene or Arctinus of Miletus and so on ${ }^{9}$. The way how Homer's Oddysey treats the issue of earning Kleos and Achilles' frustrated dwelling in the House of Hades significantly differs from depiction of Achilles' joyful afterlife in Elysium as it can be seen in Arctinus' Aethiopis ${ }^{10}$. It is clear that both traditions follow almost contradicting theories related to Kleos' impact on hero's afterlife. Homer's Iliad and Odyssey treat Kleos as a reward, which immortalises heroes in epic songs, though Kleos certainly has no power to determine whether the hero's spirit ends up in Elysium, House of Hades or even ventures to Mount Olympus.

\section{Contradicting Traditions}

Nevertheless, the Iliad, the Odyssey and fragments of the Epic Cycle altogether highlight the importance of earning Kleos for any hero, which means that Achilles' story follows Jung's / Campbell's pattern, which leads to hero's return with elixir ${ }^{11}$. Hence, Achilles story is successfully fulfilled by killing Hector and thus earning Kleos Aphthiton unperishable glory ${ }^{12}$. Achilles' death and

\footnotetext{
${ }^{9}$ For more detailed information on distinct oral tradition see - Burgess, Jonathan S. "Performance and the Epic Cycle." The Classical Journal 100.1 (2004): 1-23.

${ }^{10}$ West, Martin. "Greek Epic Fragments from the Seventh to the Fifth Centuries BC Cambridge." (2003), p. $125-126$

${ }^{11}$ Campbell, Joseph. The hero with a thousand faces. Vol. 17. New World Library, 2008, p. 170, see also - Jung, Carl Gustav. The archetypes and the collective unconscious. Routledge, 2014, p. 6, 117 12 Homer, The Odyssey, book XI.547-557: "But you, Achilles, there's not a man in the world more blest
} 
afterlife both described in the Odyssey and Epic Gycle should not be treated as part of Achilles' journey and therefore Achilles' decision between Kleos and Nostos should be interpreted as result of decision per se, since according to Jungian concept of Hero's Journey, the hero always go ahead and that is why there is no real decision, which makes the hero turn back. In other words, there are only choices that are presented to the hero, though the hero to get elixir and fulfil his innate desire and heroic role is predetermined to follow the path to the elixir - Achilles' Kleos.

Dynamical application of Hero's

Journey by Jung/Campbell is further established in Homer's Odyssey by Odysseus' fear that he will be deprived of his Kleos, when he stays with voluptuous Calypso, instead of proceeding toward Nostos and sailing home to Ithaca $^{13}$. Consequently, we can observe that earning Kleos means to go for Kleos since passivity in Homeric structure of hero's journey leads inevitably to the loss of Kleos. Such theory can be demonstrated on an example of Telamonian Ajax and his dispute with Odysseus over Achilles' armour and subsequent madness when he loses the competition and starts to slaughter sheep in a frenzy ${ }^{14}$. Talemonian Ajax deviates from a heroic pattern, and he is deprived of Kleos through his shameful action, and therefore he kills himself since there is apparently no space for reparation once Kleos has been detached from hero's journey. To put it differently, Homeric hero is on the right path to earn Kleos, only if he plunges into the central stream of Heideggerian concept of the River of Time and feels his mortality, but the hero pursues Kleos nonetheless ${ }^{15}$. Homeric tradition conveys this feeling called an aristeia

than you - there has never been, never will be one. Time was, when you were alive, we Achaeans honoured you as a god, and now down here, I see, you lord it over the dead in all your power. So grieve no more at dying, great Achilles."

${ }^{13}$ Homer, The Odyssey, book V.223-232: „So then, Royal son of Laertes, Odysseus, man of exploits, still eager to leave at once and hurry back to your home, your beloved native land? Good luck to you, even so. Farewell! But if you only knew, down deep, what pains are fated to fill your cup before you reach that shore, you'd stay right here, preside in our house with me and be immortal. Much as (excellence), which describes moments of hero's outstanding performance on the battlefield usually leading to Kleos, though such moments might result in the beautiful, heroic death, which imprints hero's glory into mythos through poet's performance again and again. In conclusion, when a poet is performing the Illiad, Achilles' fate in the Odyssey or the Epic Cycle is not relevant, since the rest of folklore's corpus is not meant to form one long and coherent story. Hence, the concept of Achilles' Kleos functions perfectly as long as it is being framed by story structure and plot of the Iliad. Furthermore, it gets even more apparent when we realise that even Hesiodic fragments of Cheironos Hypothekai mention very young Achilles and his training in heroic virtues and religious customs, but Hesiod does not mention Kleos at all ${ }^{16}$.

However, Richard Janko argues that based on "innovative phraseology and diminished old formulae", Hesiod's poems should not be considered older than the Iliad or the Odyssey, even though they chronologically deal with older and creation myths ${ }^{17}$. Hesiod evidently does not purposely took away Kleos from Achilles' destiny in Cheironos Hypothekai, though it implies that we deal with slightly different variations of Achilles in the set of Greek mythoi. The presence of underlying moral paradigm to reduce human's role as God's obedient servants can be traced down in other Hesiod's works such as Theogony, Works and Days and Catalogues of Women ${ }^{18}$. To put is simply, Hesiod's central focus is on Ponos (hardship) and its importance in the process of obtaining glory. Hesiod's inclination to Ponos is demonstrated in his high regards for Heracles in Works and Days, and because we know that Heracles earned Kleos only after he

you long to see your wife, the one you pine for all your days...

${ }^{14}$ West, Martin. "Greek Epic Fragments from the Seventh to the Fifth Centuries BC Cambridge."

(2003), p. 127-128

${ }^{15}$ Heidegger, Martin. Being and time: A translation of Sein und Zeit. SUNY Press, 1996, p.184

${ }^{16}$ Nagy, Gregory, "Hesiod," in Ancient Writers, ed. T. J. Luce (New York, 1982) 43-74

17 Janko, Richard, Homer, Hesiod and the Hymns. Diachronic Development in Epic Diction

(Cambridge, 1982).p. 189.

${ }^{18}$ Nagy, Gregory, "Hesiod," in Ancient Writers, ed.

T. J. Luce (New York, 1982) 43-74 
completed his twelve labours, we can convincingly say that Hesiod's view of Kleos is closely tied to Ponos ${ }^{19}$. It says a great deal about Hesiodic temperate view of Heroic Age compared to Homeric lavish celebration of heroic qualities.

The Iliad's book IX emphasises that Achilles had a choice to decide between going to war and fighting Trojans or living a peaceful and comfortable life of an average man. It also implies that Achilles had known consequences of both decisions and their unavoidable impacts on his ability to earn Kleos or Nostos. While various opinions claim that Achilles' decision to pursue Kleos in the Trojan War is connected primarily to his unshakable belief in fulfilling the destiny, which seems to be unalterable with possibility of earning both Kleos and Nostos. Achilles continues to fight even after he is told by his mother Thetis that his further participation in the Trojan war will result in his inevitable death, though he will earn Kleos and he will never be forgotten, which seems to outweigh considerably his desire to obtain Nostos as well ${ }^{20}$. Even more remarkable is the fact that Achilles' complete withdrawal from Trojan war appears to be almost impossible outcome due to the low value of earning Ponos in comfortable life as oppose to Kleos, which is the most desired value and cannot be earned in peaceful life. In spite of Achilles' disillusionment from being death during conversation with Odysseus in the House of Hades portrayed in the Odyssey, Achilles feels comforted by Odysseus that his imperishable glory lives on ${ }^{21}$.

Gregory Nagy goes even further by suggesting that Kleos in Homer's Iliad stands for an ability to choose the right moment for the heroic death, but Nagy's interpretation does not correspond to Homer's general concept of Kleos as it is demonstrated in a case

\footnotetext{
${ }^{19}$ Hesiod, Works and Days 287-292

${ }^{20}$ Homer, The Iliad, book IX. 410-416

${ }^{21}$ Homer, The Odyssey, book XI.547-557

${ }^{22}$ Zanker, Graham. The Heart of Achilles:

Characterization and Personal Ethics in the Iliad. University of Michigan Press, 1996, p.16, 139 Zanker theorises about potential connection between "duty" in modern linguistic sense and "time" (honour) in Archaic Greek

${ }^{23}$ Homer, The Iliad, book V.864-909: „There the thrust landed, tearing the flesh, and Diomedes wrenched it free again. Then brazen Ares bellowed
}

of Patroclus and Odysseus. Few would disagree with Nagy that Achilles joined the battle, while he was finally prepared to die for Kleos, but we should focus more carefully on Achilles' motivation and purpose for joining the battle precisely after Patroclus' death. Neither destiny or narcissist desire to earn Kleos force Achilles to fight Trojans, but it is Achilles' duty to honour Patroclus by outstanding performance on the battlefield and the fact that Achilles vows to honour Patroclus by Kleos means that Kleos can also be dedicated to someone - to honour someone's glory ${ }^{22}$. Thus, Kleos can serve as a commemoration of fallen brothers at arms in a sacrificial act of killing enemies on the battlefield and therefore expanding the Kleos of both living and fallen hero. However, it does not mean that Kleos is inevitably connected to the epic moment for dying, since full-fledged human Diomedes empowered by aresteia (excellence) earns Kleos by charging against Ares and severely wounds the god of war, forcing him to retreat from the battle ${ }^{23}$. Additionally, Odysseus earns Kleos as "ptoliporthos" - sacker of cities in The Sack of Ilium, while he ultimately re-defines new heroic dimension of Kleos in the Odyssey by earning Kleos through finishing ten-year Nostos, which in turn requires Ponos ${ }^{24}$.

Judging by examples of Diomedes and Odysseus, Kleos in Homeric tradition is not linked with the necessity of hero's epic momentum of death advocated by Nagy. Why then Achilles "the best of the Achaeans" needs to die on the battlefield as appose to Odysseus or Diomedes? It is crucial to realise that Achilles is still alive by the end of Iliad, though his death is performed by the poet in present tense only in the Aethiopis after he crushes both Penthesileia and Memnon ${ }^{25}$. It is evident that both Penthesileia and Memnon are incorporated later in the Epic Cycle to fill the

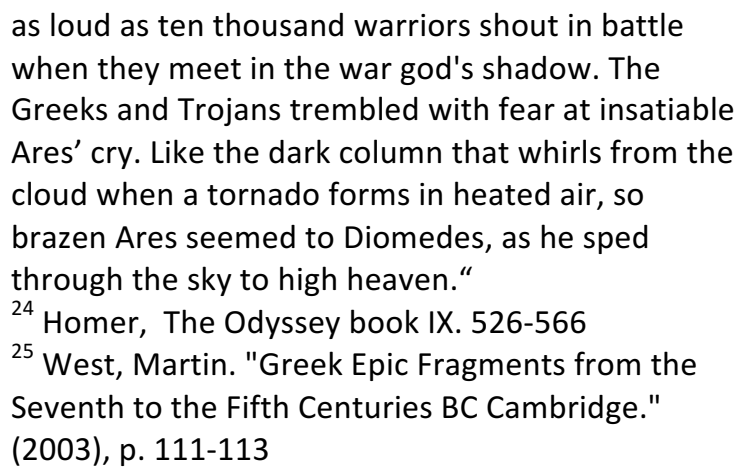


role of worthy opponents for Achilles since Hector is already dead. Achilles decides to fight and kill Memnon because he wants to avenge Nestor's son, even though Achilles is instructed that killing Memnon triggers his own to death, but he selflessly avenges Nestor's son nonetheless ${ }^{26}$. At this point, it is important to unfold deeper value of Kleos, which is not only qualitative as Gregory Nagy suggested, but it is quantitative as well because Achilles' killing spree in the Aethipois earns him, even more, Kleos before he is cowardly killed by Paris ${ }^{27}$. Henceforth, Odysseus embodies the role of epic poet or bard during Achilles' funeral, while he imprints Achilles' Kleos by his celebratory speech at Achilles' pyre ${ }^{28}$. Moreover, it is crucial to realise that Achilles' determination to pursue Kleos is not only connected to his life or honouring Patroclus, but it also influences a life of his son Neoptolemus, since Kleos is apparently transferable from father to son. However, Homer's Iliad ends with Hector's funeral, and at the time Achilles is still alive, though Homer gives us clear evidence in the Odyssey that Achilles in underworld asks Odysseus about Neoptolemus, which demonstrates that Achilles shows remarkable concern about Neoptolemus' acts ${ }^{29}$.

\section{Hereditary Kleos and Poetic Kleos}

Transference of Kleos from father to son is an important point, which shall be further demonstrated on an example of Telemachus' anxieties related to a possibility that his father Odysseus died on his voyage home in a shameful way, and therefore Telemachus might be stripped of Kleos, which supposed to be earned by Odysseus ${ }^{30}$. Moreover, the Odyssey gives us explicit evidence that Telemachus prepares himself to

\footnotetext{
${ }^{26}$ West, Martin. "Greek Epic Fragments from the Seventh to the Fifth Centuries BC Cambridge." (2003), p. 111-113, p. 112

${ }^{27}$ Nagy, Gregory. "The best of the Achaeans." (1999).

${ }^{28}$ West, Martin. "Greek Epic Fragments from the Seventh to the Fifth Centuries BC Cambridge." (2003), p. 113, 117

${ }^{29}$ Homer, The Odyssey book XI.526

30 Jones, Peter V. "The Kleos of Telemachus: Odyssey 1.95." The American Journal of Philology 109.4 (1988): p. 496-500
}

embody the role of his father when he sends his mother Penelope to her quarters to deal with her suitors ${ }^{31}$. Hence possibility of hereditary value of Kleos should not be dismissed in the case of Achilles and Neoptolemus either, since we know that Neoptolemus joined the war only after Achilles' death and proved to be crucial character by the end of the conflict as if he symbolically carried Kleos of his father Achilles onto the battlefield of Troy. However, the idea of hereditary Kleos remains subject of heated scholarly debates, but it is possible to support theories about inherited Kleos by historical evidence. We can further bolster the argument of hereditary Kleos by drawing parallel with customs and traditions related to hereditary rights in Greek families or households throughout Greek Archaic period ${ }^{32}$.

The head of the household is always the eldest man of the family, which is ideally a husband and father of the first-born son, though the first-born son remains relatively powerless and dependable on father's will and actions ${ }^{33}$. For this reason, the future of the firstborn son is directly intertwined with father's ability to link family's name with glory, honour, shame and so forth ${ }^{34}$. In other words, we should see this concept as a form of son's "starting point", which is widely influenced by father's decisions and deeds, but it does not ultimately determine that son must follow either father's footstep. In the case of Kleos, which is universally seen as positive in Homeric tradition, we can talk about the hereditary capacity for earning Kleos and therefore society's expectation of son being able to live up to father's glory or even surpassing it. For this purpose, we can observe Neoptolemus desperately charging to the battle among first of Achaeans and killing prominent Trojan characters such as King Priam at the divine

\footnotetext{
${ }^{31}$ Homer, The Odyssey book II. 409-414 - "So mother, go back to your quarters. Tend to your tasks, the distaff and the loom, and keep the women working hard as well. As for giving orders, men will see to that, but I most of all, I hold the reins of power in this house."

${ }^{32}$ Bassi, Karen. "Homer's Achaean Wall and the Hypothetical Past'." Wohl (ed.) (2014): 122-141

${ }^{33}$ Aristotle, Book III, 1280b.30-1281a.3, see also Aristotle, Book VII, 1323b.1

${ }^{34}$ Whitley, J. "Early States and Greek Heroes: A Reappraisal”. Journal of Hellenic Studies. Vol. 108 (1988) pp. 173-182
} 
altar to prove that he is worthy of Achilles' Kleos $^{35}$.

To distinguish Neoptolemus' reputation of the brutal savage from Homeric portrayal of Achilles's son, we need to identify additions from later interpretations in Classical Athenian plays such as Philoctetes or Virgil's Aeneid to put them in cultural context.

According to Mary Blundell, Sophocles' play Philoctetes was performed in 409 BC fort the first time and it clearly incorporated positive moral traits of Neoptolemus rather than the central Homeric theme of Kleos ${ }^{36}$. Conversely, Virgil's Aeneid portrayed Neoptolemus as an epitome of the cruellest behaviour, which corresponds with Roman's beliefs that Trojans were their ancestors of Romulus and Remus because of Aeneas and therefore Virgil's depiction of Neoptolemus as a slayer of poor infants and notorious rapist of Trojan women make complete sense ${ }^{37}$. Furthermore, Romans could not care less for the concept of Kleos, since earning eternal glory in the Roman Republic was linked with defeating an enemy by cooperation and superior strategy rather than individualistic heroic momentum on the battlefield.

Following Virgil's example, Gaius Julius Hyginus continued to expand Neoptolemus' negative reputation in his collection of myths called Fabulae, which has been criticised by modern folklore scholarship, though it serves as real evidence of antipathetic portrayal of Neoptolemus alongside popular Aeneid ${ }^{38}$. Unfortunately, contemporary scholarship is unable to define, whether the Roman version of Neoptolemus originated

\footnotetext{
${ }^{35}$ West, Martin. "Greek Epic Fragments from the Seventh to the Fifth Centuries BC Cambridge." (2003), p. 145147

${ }^{36}$ Blundell, Mary Whitlock. "The Phusis of Neoptolemus in Sophocles' Philoctetes." Greece and Rome (Second Series) 35.02 (1988): 137-148, for further criticism of Sophocles manipulation with the image of Neoptolemus, see Easterling, P. E. " Philoctetes" and Modern Criticism." Illinois Classical Studies 3 (1978): 27-39.

${ }^{37}$ Aeneid book II. 662-3, see also Aeneid book II. 526-532

${ }^{38}$ Rose, H. J. "Second thoughts on Hyginus." Mnemosyne 11.Fasc. 1 (1958): 42-48.

39 Elmer, David. "Oral-Formulaic Theory." In Finkelberg 2011, vol. 2. pp. 604-07
}

from distinct oral tradition or Romans simply attributed different moral explanation to the original literary version of the Iliad, which was available for Romans at the time. On the contrary, we know that Greeks in Classical period still used both literary versions of the Iliad, the Odyssey or the Epic Cycle and oral version of same stories as well ${ }^{39}$. For this reason, Richard Martin synthesises an act of performance with an act of speech and suggests that oral tradition of Homeric songs is unique in its dramatisation, lamentation and so on ${ }^{40}$. Consequently, we might argue that notion of Kleos and Nostos in the Epic Cycle is presented differently through passing down stories in the narrative style as oppose to the rendition of Homeric poetry. At the same time, it is necessary to focus on John Porter's deconstruction of the previous notion pioneered by Milman Perry, who argued that Homeric poetry can be compared to bard's poetry from former Yugoslavia ${ }^{41}$. Porter claims that Perry's findings related to Homeric poetry correspond with the style of rendition attributed to Yugoslavian bards, though the structure of Homer's poetry is evidently more elaborated and randomly selected parts cannot be performed separately as oppose to Yugoslavian counterparts ${ }^{42}$. Faulkner noted that such unfortunate connection was probably caused by Perry's deduction that shorter Homeric Hymns possibly preceded Homer's Iliad due to similar poetic style, though the content showed us that both genres are focused on different audience ${ }^{43}$.

A transcend moment of heroic poetry in the Iliad is particularly the part, when

\footnotetext{
${ }^{40}$ Martin, Richard. 1989. The Language of Heroes: Speech and Performance in the Iliad. Ithaca NY ${ }^{41}$ Parry, Milman, and Adam Parry. The making of Homeric verse: The collected papers of Milman Parry. Oxford University Press on Demand, 1987, p.468

${ }^{42}$ Hopkins, David. "The Cambridge Companion to Homer, and: The Printed Homer: A 3000 Year Publishing and Translation History of the Iliad and the Odyssey, and: The Homeric Hymns: A Translation, with Introduction and Notes (review)." Translation and Literature 15.1 (2006): p. 97-104. ${ }^{43}$ Faulkner, Andrew. 2011. Modern Scholarship on the Homeric Hymns: Foundational Issues. In The Homeric Hymns: Interpretative Essays. Edited by Andrew Faulkner. 1-25. Oxford, UK: Oxford University Press
} 
Achilles plays on cithara and performs heroic poetry in front of Patroclus, commemorating great heroes of the past, which reflects the tradition of oral transmission of heroic epics within the Iliad and therefore it solidifies the importance of Kleos and performer's reputation, while he delivers the Iliad to the audience as mythos ${ }^{44}$. This scene reminds us of the extremely powerful moment of symbolic channelling of Kleos from the mythological story into poet's performance, who thus imprints Kleos into folk beliefs as the robust and unshakable pillar of heroic legacy. As the heroes passed down Kleos from father to son, so the verses of their dauntless acts were passed down through oral tradition. Hence, heroes like Odysseus, Achilles and Diomedes truly earn their Kleos Aphthiton (imperishable glory) by engraving their names into epic verses and so their lionhearted deeds have echoed through eternity.

Martin Mares

\footnotetext{
${ }^{44}$ Homer, Iliad book IX. 182
} 
Primary Sources:

\section{References}

Aristotle. Complete works of Aristotle. Ed. Jonathan Barnes. The Oxford transl. Oxford University Press. Oxford 1984

Hesiod. Theogony. Cambridge, MA.,Harvard University Press; London, William Heinemann Ltd. 1914.

Hesiod. Works and Days. Cambridge, MA.,Harvard University Press; London, William Heinemann Ltd. 1914.

Homer. Homeri Opera in five volumes. Oxford, Oxford University Press. 1920

Homer. The Odyssey. Rendered into English prose for the use of those who cannot read the original. Samuel Butler. Based on public domain edition, revised by Timothy Power and Gregory Nagy. A. C. Fifield, London. 1900

Vergil. Aeneid. Theodore C. Williams. trans. Boston. Houghton Mifflin Co. 1910

\section{Secondary Sources:}

Bassi, Karen. "Homer's Achaean Wall and the Hypothetical Past'." Wohl (ed.) (2014): 122-141.

Blundel, Mary Whitlock. "The Phusis of Neoptolemus in Sophocles' Philoctetes." Greece and Rome (Second Series) 35.02 (1988): 137-148.

Boedeker, Deborah. "Epic heritage and mythical patterns in Herodotus." Brill's Companion to Herodotus. Brill, 2002. 95-116.

Burgess, Jonathan S. "Performance and the Epic Cycle." The Classical Journal 100.1 (2004): 1-23

Campbell, Joseph. The hero with a thousand faces. Vol. 17. New World Library, 2008.

Easterling, P. E. "Philoctetes" and Modern Criticism." Illinois Classical Studies 3 (1978): 27-39.

Elmer, David. “Oral-Formulaic Theory.” In Finkelberg 2011, vol. 2. pp. 604-07

Faulkner, Andrew. 2011. Modern Scholarship on the Homeric Hymns: Foundational Issues. In The Homeric Hymns: Interpretative Essays. Edited by Andrew Faulkner. 1-25. Oxford, UK: Oxford University Press

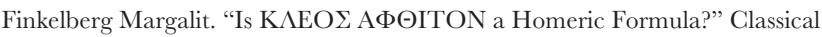

Quarterly, 35:1-5.

Heidegger, Martin. Being and time: A translation of Sein und Zeit. SUNY Press, 1996

Hopkins, David. "The Cambridge Companion to Homer, and: The Printed Homer: A 3000 Year Publishing and Translation History of the Iliad and the Odyssey, and: The Homeric Hymns: A Translation, with Introduction and Notes (review)." Translation and Literature 15.1 (2006): 97-104.

Janko, Richard, Homer, Hesiod and the Hymns. Diachronic Development in Epic Diction (Cambridge, 1982).

Jones, Peter V. "The Kleos of Telemachus: Odyssey 1.95." The American Fournal of Philology 109.4 (1988): 496-506.

Jong, Irene JF. Narrators and focalizers: the presentation of the story in the Iliad. Bristol Classical Press, 2004.

Jung, Carl Gustav. The archetypes and the collective unconscious. Routledge, 2014.

Kirk, Geoffrey Stephen. The Iliad: A Commentary: Volume 4. Ed. Richard Janko. Cambridge University Press, 1991.

Mackie, Hilary. "Song and storytelling: an Odyssean Perspective." Transactions of the American Philological Association (1974-) 127 (1997): 77-95.

Martin, Richard. The Language of Heroes. Speech and Performance in the Iliad (Ithaca and London, 1989

Nagy, Gregory, "Hesiod," in Ancient Writers, ed. T. J. Luce (New York, 1982) 43-74

Nagy, Gregory. "The best of the Achaeans." (1999).

Parry, Milman, and Adam Parry. The making of Homeric verse: The collected papers of Milman Parry. Oxford University Press on Demand, 1987.

Page, Denys Lionel. History and the Homeric Iliad. Vol. 31. University of California Press, 1976.

Porter, John. The Iliad as Formulaic Poetry

Rose, H. J. "Second thoughts on Hyginus." Mnemosyne 11.Fasc. 1 (1958): 42-48.

Segal, Charles. "Kleos and its Ironies in the Odyssey." L'antiquité classique (1983): 22-47.

West, Martin. "Greek Epic Fragments from the Seventh to the Fifth Centuries BC Cambridge." (2003)

Whitley, J. "Early States and Greek Heroes: A Reappraisal". Journal of Hellenic Studies. Vol. 108 (1988) pp. 173-182

Zanker, Graham. The Heart of Achilles: Characterization and Personal Ethics in the Iliad. University of Michigan Press, 1996. 